\title{
O INSÓLITO LUGAR CAÍDO NO CREPÚSCULO, DE JOÃO DE MELO
}

Cristina Costa Vieira (UBI)

Recebido em 19 mai 2015. Cristina Costa Vieira - Professora Auxiliar do Aprovado em 04 nov 2015.

Departamento de Letras da Universidade da Beira Interior, Portugal (2005). Directora do Mestrado em Estudos Didáticos, Culturais, Linguísticos e Literários, Investigadora integrada do Centro de Literatura Portuguesa, da Universidade de Coimbra. Doutora em Teoria da Literatura e Literatura Comparada (UBI, 2005); Mestre em Estudos Portugueses e Brasileiros (FLUP, 2000); Licenciada em Línguas e Literaturas Modernas - Estudos Portugueses e Franceses (FLUP, 1996). Currículo na base FCT. Contacto: cvieira@ubi.pt

Resumo: $\mathrm{O}$ insólito marca o mais recente romance de João de Melo, prestigiado escritor português contemporâneo de raízes açorianas. De facto, Lugar caído no crepúsculo (2014) constitui uma visão heterodoxa de um possível Além, que desconstrói o imaginário popular açoriano, fortemente marcado por superstições mantidas pela influente Igreja Católica desse arquipélago português, tradições bíblicas milenares e eruditos palimpsestos renascentistas, com destaque para A divina comédia, de Dante, e o Auto da barca do Inferno, de Gil Vicente. Evidenciamos, nesta análise, a insólita espacialização dos lugares desse Além ficcionado por João de Melo.

Palavras-chave: Insólito; João de Melo; Além; Espaço; Desconstrução. 
Abstract: The unusualness marks the latest novel by João de Melo, the prestigious contemporary Portuguese writer with Azorean roots. Indeed, Lugar Caído no Crepúsculo (2014) is an unorthodox view of a possible hereafter that deconstructs the popular Azorean imaginary, strongly superstitious, due to the influent Catholic Church of this Portuguese archipelago, ancient biblical traditions and erudite Renaissance palimpsests, highlighting Dante's The Divine Comedy and Gil Vicente's Auto da Barca do Inferno. In this analysis, we point out the unusual spatial ficcionalization of João de Melo's hereafter.

Keywords: Unusualness; João de Melo; Hereafter; Space; Deconstruction.

\section{HETERODOXIA E INSÓLITO}

A heterodoxia opõe-se à doxa, isto é, àquilo que é considerado verdadeiro, donde Maria de Fátima Marinho ter cunhado a expressão focalização heterodoxa para designar os romances históricos cujas perspectivas se apresentam "radicalmente opostas às da História oficial" (1999, p. 233) e que, obviamente, visam surpreender o leitor de acordo com intentos autorais vários. Julgamos, pois, não ser um abuso interpretativo equivalermos o termo heterodoxo à expressão "insólito ficcional" (GARCÍA, 2012, p. 14), que designa, de acordo com Flavio García, "a irrupção do inesperado" (2012, p. 14) no contexto específico de uma narrativa, traço comum a diversos géneros literários, a exemplo do Fantástico europeu oitocentista e do Realismo Maravilhoso sul-americano. Ora, essa irrupção entra "em desconformidade com a lógica racional e o senso comum" (GARCÍA, 2012, p. 24), quebrando expectativas consideradas mais plausíveis pelo leitor no quadro do real quotidiano. Ou seja, o insólito assenta em 
desvios às probabilidades pascalianas e/ou rompe com a lógica aristotélica, o que também pode ser ilustrável a partir de autores como Kafka (GARCÍA, 2012, p. 23). Adverte, porém, Carlos Reis que até obras realistas como Os Maias (1888) se centram no insólito, dado o inverosímil reencontro e enamoramento de dois irmãos separados na infância, cujo parentesco é de ambos, inicialmente, desconhecido. Isto obriga a um reequacionamento do termo insólito em função do contexto histórico, dado que o Iluminismo racionalista havia varrido para o campo da superstição noções antes tidas como naturais, a exemplo do destino, que parece actuar naquele romance realista (REIS, 2012, p. 54-59). O mesmo ensaísta refere ainda múltiplos romances de Saramago classificados, "sem reticências, ficções do insólito" (REIS, 2012, p. 67). Nesta perspectiva, o nosso artigo "Heterodoxias ficcionais e historiográficas no romance saramaguiano: o desejo e a morte em História do cerco de Lisboa e As intermitências da Morte" (VIEIRA, 2012) aborda casos de insólito ficcional, segundo a terminologia de Flavio García.

De acordo com o semiótico boliviano Renato Prada Oropeza, o efeito de inesperado pode ser conseguido ao nível do tempo, do espaço, das personagens e da relação autor-leitor-narrativa (GARCÍA, 2012, p. 17). Focaremos a espacialização insólita no mais recente romance de João de Melo (1949-), Lugar caído no crepúsculo (2014), um título que remete, desde logo, para a importância do espaço como "componente gerador de sentidos" (GAMA-KHALIL, 2012, p. 31), a exemplo do que sucede nas narrativas kafkianas, cujos espaços físicos fechados enfatizam a situação (denotativa ou conotativa) de encarceramento dos 
protagonistas. A tal ponto o espaço é gerador de sentidos que a abertura e o fechamento espaciais determinam "algumas categorizações da personagem" (VIEIRA, 2008, p. 287):

Assim, a topicalização de tipo fechamento espacial costuma permitir a identificação categorial da personagem num rígido esquema de distribuição de papéis hierárquicos que o espaço fechado tende a marcar: a topicalização narratológica de uma personagem num orfanato indicia-a, em princípio, como criança órfã ou como funcionário da instituição; a prisão, como prisioneiro ou como guarda prisional; o seminário, como seminarista ou padre. [...] § [...] Esta determinação categorizante da personagem também ocorre na abertura espacial: o cimo da montanha gelada pode determinar o aventureiro ou o alpinista; o cimo do arranha-céus, o citadino ou o cosmopolita; o alto mar, o marinheiro ou o pescador; a pradaria do oeste selvagem, o índio ou o cobói solitário. (VIEIRA, 2008, p. 287-288)

Ora, o espaço, por excelência, que desafia expectativas, gera inquietações ou cimenta fés é o do Além. Esse se coloca ao homem não apenas como um tempo post mortem, sinónimo de eternidade, de intervalo entre reencarnações ou de vazio, de acordo com a crença ou ausência dela, mas também como um espaço para onde a alma se desloca após o desprendimento carnal, tenha esse a dimensão ontológica que tiver, ou seja, ele como for, ou então como um não espaço, quando a morte é encarada como o fim da ipseidade. Por isso, o espaço post mortem tem desafiado a imaginação descritiva literária e originou, por exemplo, indica Rosado Fernandes, o topos clássico da catábase ou descida aos Infernos, a partir do mito de Orfeu e dos diálogos de Ulisses com as almas residentes no "Hades de fortes portões" (HOMERO, 
XI, p. 277). Já as catábases, presentes na Eneida (canto VI) e n'A Divina Comédia, embora perpetuem a soturnidade e a tragicidade homéricas, adaptam as obras ao sentido religioso das respectivas épocas: à pietas romana, em Vergílio (FERNANDES, 1993, p. 348), e "ao cristianismo e à realidade histórico-literária", em Dante, e daí que o poeta florentino encontre na sua viagem fantástica "figuras conhecidas da história, da literatura e do pensamento europeu medieval" (FERNANDES, 1993, p. 349). Apontando outros exemplos, mais ou menos próximos do modelo clássico, Rosado Fernandes adverte, contudo, que a catábase só está presente numa obra onde seja descrita uma efectiva descida aos infernos; caso contrário, trata-se de uma "interpretação simbólica" desse topos (FERNANDES, 1993, p. 358). A descrição do Além tem despertado, pois, o fascínio de vários autores, entre os quais João de Melo (1949-), escritor português, de raízes açorianas, pertencente à geração literária do pós-25 de Abril, notabilizado, sobretudo, a partir do romance Gente Feliz com Lágrimas (1988), que conheceu adaptação televisiva e teatral.

\section{JOÃO DE MELO E O TEMA DA MORTE}

A morte é um tema recorrente e heterodoxo em João de Melo. Por exemplo, o incipit de Entre pássaro e anjo (1990) mostra a personagem principal a narrar, em analepse, a sua morte, situando o protagonista num tempo e espaço "transcendentais", que recordam a estrutura das machadianas Memórias póstumas de Brás Cubas (1888):

Quase não tem história o modo simples mas pouco simpático como nessa tarde o Pai destinou matarme. Se decido contá-lo é tão-só porque isso me 
trouxe alguma experiência e o desejo transmitir aos vivos. A minha única intenção consiste em sossegarvos quanto aos pormenores da angústia que estraga em vão a breve e sempre tão miserável existência dos homens. Na verdade, morrer é coisa fácil e leve - e não dói. [...] § [...] Se as pessoas acreditassem na tranquilidade e no repouso que se sucede ao momento da agonia, o espírito da paz facilmente emendaria os erros do mundo. (MELO, 1990, p. 11)

Essa estrutura, in ultimas res, é insólita enquanto forma menos usual nas narrativas e enquanto situação inesperada de colocar um narrador-personagem a falar $a b$ initio para o narratário-leitor na condição de morto.

O tema do Além surge novamente de forma nuclear na novela A divina miséria (2009), a propósito do funeral do totalitário Padre Governo, senhor temporal e espiritual das terras açorianas do Nordeste, idolatrado até à histeria pelas beatas locais, mas cuja prepotência sonegara aos pobres habitantes desse espaço micaelense "um pouco de alegria", a "esperança no Céu" ou na “justiça terrena" (MELO, 2009, p. 46-47). Diz então o narradorpersonagem, testemunha e participante forçado nas exéquias do detestado clérigo, a um narratário identificado como escritor e surpreso com a confissão que se segue:

O meu doentio fascínio pelos mortos! Sabe o que me inebria e ao mesmo tempo repugna no repouso final dos seus corpos tão frios? A rigidez dos ossos. O friúme azulado dos músculos faciais. A altivez da sua desgraça. O modo, percebe o senhor? Como os mortos me parecem únicos - unos e iguais entre si. Na vida, como se sabe, as pessoas cultivam e alimentam as suas diferenças. [...] A morte é a democratização absoluta dos vivos: o fim de toda a 
discriminação. [...] § Além disso, se coisas há que eu adoro é ir a funerais e visitar cemitérios. O senhor, não? Pois bem, é para mim um regalo entrar por ali dentro, ir de campa em campa e de mausoléu em mausoléu lendo os nomes, as datas, um ou outro epitáfio [...]. Tudo tão pungente, mas afinal bem à nossa medida. A terra é um mistério, a morte é outro, e eu adoro os mistérios, os silêncios [...]. Para mim a morte não é essencialmente subterrânea, mas antes alta, aérea, porosa, entre cão e lobo, toda ela em ascensão para a montanha mais alta da Terra ou da Lua. (MELO, 2009, p. 24-25).

Esta estesia da morte confessada pelo narrador-personagem não se compagina nem com o ultrapassado ultrarromantismo de um Soares de Passos nem com a estética simbolista de um Camilo Pessanha. Aposta, isso sim, na morte enquanto "fim de toda a discriminação" terrena, ideia já presente em Horácio, que afirmava bater a "pálida Morte [...] com imparcial pé à porta da cabana dos pobres / e dos palácios dos reis." (HORÁCIO, I, 4, p. 13-14). De realçar o seguinte no romancista português: João de Melo aposta na recusa da localização topográfica do Além nos tártaros subterrâneos, como evidencia a frase final da passagem supracitada. Essas perspectivas serão adoptadas no romance Lugar caído no crepúsculo, texto ficcional que sucede, em termos de publicação, à Divina miséria, expandindo teológica e filosoficamente a descrição do Além, referido de forma sumária nas páginas finais da novela, cujo autor se projecta quer no narrador quer no narratário, como verificamos nas páginas finais do texto:

Deus não quis ouvir o protesto das nossas vozes, nem o estouro dos nossos foguetes, no dia dos 
funerais de sua santidade o Padre Governo. [...] Apesar disso, senhor, é bem possível que Deus exista. § Existe ou existirá, ainda que demorando excessivamente no Seu caminho de regresso aqui, ao meu espírito, na vontade de Céu, Limbo, Inferno ou Purgatório (a mim tanto se me dá.) Basta que me aconteça uma simples morte doce, de tão desejada, e tão amiúde escrita e profetizada nos seus papéis de escritor. (MELO, 2009, p. 116).

\section{O INSÓLITO ESPACIAL EM LUGAR CAÍdO NO CREPÚSCULO}

A escrita de João de Melo insere-se num Ocidente contemporâneo laico, com direito à liberdade de pensamento, de consciência e de expressão. Por outro lado, o Concílio Vaticano II (1962-1965) procurou adaptar a Igreja Católica aos tempos modernos. Ainda assim, o Catolicismo continua a reger-se por dogmas, que, entre outros, também abrangem uma concepção do Além hierarquizado e dividido entre Inferno, Purgatório e Paraíso. No sítio electrónico "Dogmas sobre a morte e o Além" do Front católico (PAGANINI, 2014), o Paraíso e o Inferno aparecem definidos desde Benedito XII (1334-1342): o primeiro é a morada das "almas completamente purificadas", onde "contemplam [...] a essência divina, vendo-a face a face", o que lhes dá "eterno descanso"; sendo o segundo o das almas "que morrem em estado de pecado mortal". Já "o purgatório é estado de purificação" de quem faleceu com pecados veniais, mas não mortais, havendo, por isso, a possibilidade de transitar para o Paraíso, um conceito novo surgido na Idade Média, por decreto de Gregório X (1271-1276) no II Concílio de Leão (1274), (PAGANINI, 2014). Nada é dito a respeito do Limbo, uma vez que esse lugar, nunca referido nos evangelhos, 
e concebido teologicamente pelos Padres da Igreja S. Agostinho (354-430) e S. Tomás de Aquino (1225-1274) para albergar as almas dos não baptizados com esperança de entrada no Paraíso, seja por terem acreditado na vinda do Messias, seja por serem crianças, foi oficialmente extinto em 2007 pela Comissão Teológica Internacional da Igreja, subordinada ao Vaticano, no papado de Bento XVI. O documento, assinado pelo papa, decreta que o limbo não é compaginável com a piedade de Deus, ou seja, reflecte uma visão excessivamente restritiva da salvação. Todavia, sectores mais conservadores da Igreja não aceitam ainda hoje tal decreto.

Lugar caído no crepúsculo, de João de Melo, é um título que utiliza uma expressão respigada ao escritor mexicano Juan Rulfo para metaforizar o sítio "onde se nos acaba a jornada", citada em epígrafe inicial, e interpretada livremente pelo autor português, fora do contexto da narrativa rulfoniana, como sendo a morte. Trata-se, pois, de um eufemismo, e os dogmas católicos sobre o Além acima mencionados são o ponto de partida para a estrutura desse romance, mas não o ponto de chegada, pois os mesmos aparecerão insolitamente desconstruídos.

Em primeiro lugar, o índice induz em erro o leitor para uma visão que parece, a priori, seguir a ortodoxia católica. Os subtítulos dos capítulos inicial e final constituem expressões retiradas de orações mundialmente utilizadas e reconhecidas como tal: "Assim na Terra como no Céu" aparece na oração mais importante do cristianismo, o Pai Nosso, presente em todos os evangelhos canónicos; e "A Luz Perpétua" é reiterada no Terço pelas Almas na frase "Dai-lhes, Senhor, o eterno descanso, e a luz perpétua os ilumine". O "Segundo Caderno", por outro lado, igualmente 
mais curto, rondando à volta de uma dezena de páginas, e com o subtítulo "O Peso da Alma", assume, à semelhança do primeiro caderno, um carácter introdutório à viagem iniciática ao Além, que aparece repartida pelos quatro cadernos seguintes, com grande espaço narrativo, intitulados "O Limbo", "O Purgatório", "O Paraíso" e "O Inferno", ou seja, os quatro espaços escatológicos tradicionais da Igreja Católica. Ora, é de frisar que João de Melo começa a sua viagem iniciática ao Além pelo Limbo, como fizera Dante n'A divina comédia em pleno século XIV (Dante, livro I, canto IV). Só que a crença no limbo era uma realidade nesse alvor do Renascimento italiano, reafirmada havia relativamente pouco tempo por S. Tomás de Aquino, que figura no Paraíso de Dante, enquanto Lugar caído no crepúsculo é um romance escrito e publicado em 2014, tendo esse lugar escatológico sido abolido pelo próprio papa Bento XVI em 2007. Teremos, então, uma perspectiva arreigadamente tradicionalista do Além em João de Melo? As roupagens ortodoxas destes subtítulos são ilusões que pretendem realçar ainda mais o insólito despertado pela leitura do romance. O mesmo objectivo subjaz à inclusão de epígrafes retiradas do Catecismo da Igreja Católica, datado de 1993, segundo Nota inicial, e que precedem a descrição do Purgatório, do Paraíso e do Inferno, ou ainda da definição tradicional de limbo inclusa por João de Melo em modo de epígrafe no início do "Terceiro Caderno". Veja-se, por exemplo, a citação feita a propósito do Paraíso: "Os que morrem na graça e na amizade de Deus, perfeitamente purificados, vivem para sempre com Cristo. São para sempre semelhantes a Deus, porque O vêem tal como Ele é, face a face." (MELO, 2014, p. 125). A descrição espacial 
do Paraíso em João de Melo não corresponderá às expectativas geradas pela epígrafe. E o mesmo sucederá com o Limbo, o Purgatório e o Inferno melianos. Na realidade, João de Melo descrê no Além, e essa descrença advém desde logo do "sufoco espiritual" (MELO, 2015, p. 32) confessado pelo próprio, que lhe foi imposto no seminário do Espírito Santo, no Fraião, em Braga, para onde seguira para prosseguir estudos que, de outro modo, não conseguiria fazer junto "ao campo e às vacas" do pai (MELO, 2015, p. 32). Vivia, adolescente, num seminário sem vocação religiosa, onde os Dominicanos exerciam uma vigilância opressiva e conservadora, mantendo vivo o medo do fogo do Inferno, que depois negara, tornando-se ateu. Mas o sobrenatural já marcara a sua infância na Achadinha natal, um cantinho dos Açores então dominado por superstições, lendas e por uma influente Igreja Católica que ainda não vivera o Concílio Vaticano II. Recorda João de Melo a infância na entrada "Açores" do Dicionário de paixões:

Aliás, tudo fora já escrito nos caprichos da talha, na pedra da pia baptismal, no frontispício das igrejas açorianas. Aprendera que um dos sete livros da Bíblia fora escrito no decurso dessa infância de sinos, tardes de catequese, dias de santos padroeiros de ruas e canadas, noites de peregrinações e novenas contra o mal dos sismos, o mal dos domingos de ter faltado à missa e o mal sem nome de não saber reproduzir de cor, e com o devido pormenor, todo o enunciado sobre a existência e sobre a história de Deus... Nesse diário sem horas, comparecia sempre um lado religioso e vulcânico, sem dúvida, diurno, que nos incitava a cometer actos pagãos e a fazer figas à bandeirinha roxa e à pomba do Divino Espírito Santo. No fim de contas, o mundo estava 
escuro desde anteontem, e a vida decorria, ainda e sempre, entre o livro do Génesis e o livro do Apocalipse... (MELO, 1996, p. 18)

A irreverência das brincadeiras de garoto com símbolos maiores do catolicismo açoriano (as festas do Espírito Santo) dão lugar à perda da fé na adolescência, apesar de João de Melo sentir o ateísmo como "uma sombra que promete afligir e assustar a nossa alma até ao fim do tempo que nos foi dado a viver", confessa na entrada "Deus" do mesmo Dicionário (MELO, 1996, p. 64); como "uma espécie de orfandade", revela em entrevista a Luís Ricardo Duarte (2014, p. 14), agudizada pelo falecimento da mãe, facto que está na génese do romance. O escritor indica nessa entrevista que a sua progenitora, a quem dedica a obra, Ihe colocou inopinadamente no leito de morte "as mesmas dúvidas que viu crescer dentro de si. "Como é que será depois de fecharmos os olhos?" [...]. "Será que Deus está lá à minha espera?" (DUARTE, 2014, p. 14).

O insólito espacial é uma das formas de João de Melo traduzir essa descrença no Além ortodoxo católico, propondo, em alternativa, um Além no qual poderia eventualmente acreditar, ainda que a indefinição do destino do protagonista do capítulo inicial pareça representar o agnosticismo do Autor. O diminutivo "alminha", utilizado pelo narrador extradiegético no primeiro capítulo do romance para se referir a esse protagonista, imprime, desde logo, um tom humorístico a uma sequência que seria ortodoxamente marcada pela seriedade, dado o tema da morte. Mas, as passagens humorísticas e coloquiais vão-se repetindo nesta viagem iniciática ao Além, e esse "fino humor 
e o pontilhado coloquialismo aliviam o timbre grave posto na figuração polifónica de um Além católico no qual o Autor descrê e que desconstrói" (VIEIRA, 2015, p. 211).

O insólito espacial irrompe logo no "Primeiro Caderno" do romance. A narrativa inicia sob o signo da mimese, com o velho actor Tomás de Mascarenhas a passear pela baixa lisboeta. O uso de topónimos como "velho Teatro Nacional", "Rua da Betesga", "Rossio", "Terreiro do Paço", "Lisboa", "Tejo" ou "Rua Augusta" (MELO, 2014, p. 13-19) imprime, pela força da referencialidade, maior verosimilhança ao recatado passeio do actor. Como indica o narrador: "Tudo o que ele escutava e via em redor de si não parecia representar qualquer novidade, nem nenhuma estranheza mais ou menos recente" (MELO, 2014, p. 14). Todavia, o inesperado irrompe quando Tomás de Mascarenhas nota a estranheza do olhar insistente e incómodo de uma mulher, estranheza que aumenta na proporção do número de olhos perseguidores, ao ponto de sentir a sua segurança ameaçada, o que leva Tomás a correr, movimento repetido por uma multidão crescente, estranhamente silenciosa e incansável, e que o leva "nessa fuga cega para o Tejo e para o nada." (MELO, 2014, p. 19). Há aqui dois tipos de insólito: a situação é inverosímil dado Tomás de Mascarenhas já não ser uma celebridade, e, mesmo que o fosse na vida real, nem todos os citadinos, sem excepção, resolveriam correr atrás de uma celebridade. 0 espaço torna-se igualmente insólito por se fazer uma associação rizomática ${ }^{1}$ entre um topónimo imediatamente reconhecível

1 Esclarecendo algo essencial a todo o romance, um rizoma, na definição de Deleuze e Guattari, dada originalmente em Mille Plateaux (1980), "é um espaço que não tem começo nem fim, [...] não é constituído de unidades, porém de dimensões movediças. O espaço do fantástico é essencialmente rizomático, seja pela sua multiplicidade significativa, seja pela ruptura que estabelece com o 'real', seja pela conexão alegórica que opera em relação ao mundo." (Apud GAMA-KHALIL, 2012, p. 36-37). 
pelo leitor português (e não só), o Tejo, e um espaço inexistente, traduzido pelo substantivo presente no SN "o nada". E esse nome parece equivaler, no início da narrativa, ao tempo e ao espaço post mortem. Confirma-se, um pouco antes da passagem supracitada, a associação rizomática de dois espaços distintos, em que o Tejo é a conexão alegórica com o Além. Veja-se, para tal, a focalização interna do rio que desagua em Lisboa dada anteriormente pelos olhos de Tomás de Mascarenhas:

O Tejo sempre lhe dera a sensação de um horizonte que estava por desvendar para além da cidade: constituíra-se na ilusão de uma largueza que se confundia com a viagem sem fim - a partida, uma porta de saída para o mundo e a verdade íntima e definitiva do seu próprio ser. [...] A sua largura, serena e gigantesca, transmitia-lhe a sensação de liberdade e distância que só é possível captar das mais belas paisagens urbanas, quando espelhadas na calma da água. O rio invocava dentro dele, não sabia ao certo porquê, um território de passagem da realidade para os sonhos." (MELO, 2014, p. 18-19)

Mais adiante, no caderno dedicado ao Inferno, recriação pósmoderna do mais famoso auto português, $A$ barca do Inferno, e com elos intertextuais à Divina comédia, de Dante, em que se mostra uma similar rudeza do barqueiro Caronte para com os seus passageiros (DANTE, livro I, Canto III, p. 94-129), a travessia para o mais temível dos espaços escatológicos faz-se novamente pelo Tejo. O rio é identificável de novo pelos topónimos que lhe são contíguos: "Rossio", "Terreiro do Paço" e "Cais das Colunas", sobremaneira este, para onde "convergia de todas as partes da cidade" uma enorme multidão "a caminho do embarque e 
da travessia do rio, rumo à outra banda", na "barca do senhor Vicente" (MELO, 2014, p. 185). O Tejo funciona no romance como um verdadeiro rizoma, por se tratar de um espaço que pode comportar diferentes analogias e ligar-se a diferentes pontos ao mesmo tempo. O rio descrito pela focalização de Tomás de Mascarenhas não parece ser o mesmo aquífero, transmitindo a esta personagem a sensação de "liberdade e distância", e, como se verá no "Epílogo", a travessia do Tejo não levará, necessariamente, o actor ao Inferno, mas a um Além ainda indefinido, sendo que esse rio é atravessado pelo protagonista do "Primeiro Caderno" a voar, enquanto a personagem que segue na barca vicentina descreve um rio bem diferente:

Sabia-o por instinto e por convicção: por ali corria e passava, sem margem para dúvidas, um rio de travessia obrigatória. Teria de procurar a linha do horizonte do lado de lá desse Tejo largo, derramado, cheio de barcos, turvo como uma poça enlameada e tão ou mais escuro do que um fosso marítimo que se afundasse até ao centro da Terra. (MELO, 2014, p. 189)

Logo, o rio Tejo, sereno e plácido, é encarado por uma personagem como "um território de passagem da realidade para os sonhos" (MELO, 2014, p. 19) e que o vai conduzir até um "Além desconhecido", um "lugar caído no crepúsculo" (MELO, 2014, p. 22-23), enquanto para outra personagem é uma temida "travessia obrigatória", um espaço dantesco, afunilador, que vai significar a passagem para o Inferno.

Regressando à situação insólita com que se depara o protagonista do "Primeiro Caderno", são várias as marcas linguísticas que enfatizam a estranheza crescente da 
personagem, como "Estranhou", "intrigante", "mistério", "paradoxo", "sonho" e "pesadelos" (MELO, 2014, p. 16). A pouco e pouco, o protagonista compreende viver "uma nova realidade verdadeira" que o enche "de um pavor frio, com o seu quê de sobrenatural" (MELO, 2014, p. 20), mas que explica "o cerco" de que é alvo, seguido de genuflexões, choros, "soluços, gemidos e suspiros" (MELO, 2014, p. 20-21): sem se dar conta, morrera e estava a ser velado. O espaço de um funeral descrito de forma muito vaga torna-se ainda mais insólito e transgressor quando João de Melo retoma em clave irreverente a duplicidade do ser humano enquanto corpo e alma. De facto, o corpo de Tomás de Mascarenhas, já cadáver, imita os que o rodeiam, sem que esses aparentem aperceber-se, e põe-se a "dizer adeus, adeus, adeus para sempre à sua alminha" (MELO, 2014, p. 22). E a condição de dois "eus" pensantes, um no corpo e outro na alma, contraria toda a tradição espiritualista ocidental, toda a ortodoxia católica, que situa o "eu" pensante na alma, donde a sua imortalidade, por oposição à perecibilidade do corpo: Tomás de Mascarenhas vê-se de repente "na condição de uma dupla pessoa" (MELO, 2014, p. 22), donde advém a surpresa da personagem. Este insólito é reforçado no início do "Sexto Caderno", que mostra o furibundo barqueiro Vicente procurando impor a ordem em vão na barca que segue para o Inferno. Nela vai um corretor da Bolsa de Lisboa, que, no final da travessia, vê o seu corpo abandonado na barca, "enquanto a alma ficava do lado de cá, na margem oposta da vida", sendo o lado de lá a margem do Tejo onde atracara, junto ao Cais das Colunas, consciencializando-se, por fim, da sua "condição de 
dupla pessoa" (MELO, 2014, p. 205). Essa duplicidade traduz uma equivalência insólita, traduzível no conceito mais uma vez de espaço rizomático, que subjaz ao subtítulo do "Primeiro Caderno", "Assim na Terra como no Céu" (MELO, 2014, p. 11). A Terra equivale ao Céu, isto é, o mundo dos vivos não será muito diferente do plano transcendente, e isso parece descartar pelo menos a esperança num Paraíso recompensador das injustiças terrenas. De facto, tal expressão evangélica frisa o "desespero humanista" (MELO, 2014, p. 155) do Autor face a um mundo que espelha o Inferno (ou vice-versa), porque dominado "desde sempre" (MELO, 2014, p. 156) por iniquidades, hoje culminadas no "apocalipse" sócioeconómico planeado pelos "senhores economistas" (MELO, 2014, p. 222). A Terra, tal como o Paraíso, não conhece a face de Deus, mas parece entregue ao Mal, tal como sucede no Inferno, onde o Demónio marca a sua presença sádica. A imagem disfórica que fecha a obra sintetiza esta ideia: a chuva divina cai "no Além e na Terra inteira, em ambos por igual." (MELO, 2014, p. 255). Mas a associação rizomática Terra/Céu é visível na narrativa de outros modos.

Para começar, o peso da alma designa, segundo texto epigrafado de Cecília Meireles, tudo aquilo que nos emociona, e constitui para a personagem referencial Duncan MacDougall (c. 1866-1920) uma "revelação" científica, que a calculou em "vinte e um gramas" (MELO, 2014, p. 27), diferença padrão verificada na pesagem de pessoas e outros animais quando vivos e mortos, e que, na dedução do clínico norte-americano, é a "prova, tão evidente, quanto irrefutável, da existência da alma" (MELO, 2014, p. 27). O "peso da alma", assim duplamente definido, polariza 
- "Segundo Caderno" e começa por negar a imaterialidade total da alma, pois, de outro modo, esta não teria peso. O conceito poético ou revelação científica do peso da alma serve de diatribe aos que perdem em vida esse peso, essa "dor [...] íntima" sinónimo de humanismo, exemplificando o narrador com os países cujos "naturais renegam a bússola patriótica, mais a dignidade histórica, mais a ideia da honra na vida concreta e abstracta de cada cidadão" (MELO, 2014, p. 31) e com os políticos que rapinam tais nações, dormindo "de um sono só, com a consciência tranquila" (MELO, 2014, p. 32). Depois, o peso da alma ou a etérea corporalidade da mesma aparece sugerida, por exemplo, nas "bordoadas" a que uma "louca extraviada" do Purgatório (MELO, 2014, p. 116-117) é sujeita por parte do marido vingativo e na identificação clara de personagens referenciais merecedoras do Paraíso (cf. MELO, 2014, p. 164-168) ou condenadas ao Inferno (cf. MELO, 2014, p. 218-221).

Novo insólito apanha então de surpresa o leitor, que aguarda ver os espaços escatológicos apontados no índice inicial serem descritos por Tomás de Mascarenhas, cujo falecimento é descrito no "Primeiro Caderno", e tendo o leitor por paradigma A divina comédia, de Dante, na qual os mesmos espaços são descritos pela personagem que inicia tal viagem, o próprio poeta. Todavia, o Autor decide mudar de protagonista quando começa a descrever o Além, deixando Tomás de Mascarenhas em suspenso até ao "Epílogo", em que a sua situação no espaço e tempo post mortem é retomada. O Limbo, o Purgatório, o Paraíso e o Inferno, por esta ordem em João de Melo, são focalizados por quatro almas que foram parar a essas estações existenciais (cf. MELO, 2014, p. 113 e 177), traduzindo, assim, um romance polifónico. As personagens- 
narradores intradiegéticos e autodiegéticos identificam-se com toda a clareza: o Limbo é descrito por Erasmo Fernandes, e ali foi "Parar logo após o acidente [...] em estado de graça" (MELO, 2014, p. 35); o Purgatório, pelo cronista Albuquerque, com faltas ainda por pagar e beneficiando da misericórdia divina de poder um dia ascender ao Paraíso; o Paraíso, por "S. B., proprietário de terras e de um palácio" (MELO, 2014, p. 156); e o Inferno, por Fernão Lourenço, corretor da bolsa de Lisboa. A relação espaçopersonagem que daqui se vislumbra é insólita e marca um primeiro sentido de "Além desconhecido" (MELO, 2014, p. 22) enquanto ignorância do destino final de uma alma, metaforizada na trajectória de Tomás Mascarenhas, vendo a sua "alma voadora [...] a seguir em frente, no azul sem fim, onde céu e mar se unem fechando portas e varandas e vigias atrás de si" (MELO, 2014, p. 22), para não lograr, no fim, o desvendar dos "enigmas sagrados do Além" (MELO, 2014, p. 243), mesmo lá estando. De facto, a ortodoxia associa o Limbo a justos e crianças não baptizadas, o Purgatório a almas querendo obter o perdão divino, o Paraíso a justos puros, como anjos e santos, e o Inferno a almas pecadoras e sem mostras de arrependimento. Ora, essa categorização de personagens em função do espaço escatológico só em parte é mantida no Além de João de Melo. Assim, continuam a merecer destaque no Limbo "Os milhões e milhões de bebés inocentes" (MELO, 2014, p. 44); no Purgatório, os "milhões de almas que não praticaram senão brandos e pacatos deslizes" e que "daqui se salvam" (MELO, 2014, p. 85); no Paraíso, o Anjo-da-Guarda do narrador-protagonista desse espaço, mais artistas, filantropos e políticos referenciais que merecem a glória divina, como Goya, 
mártires anónimos ou Salgueiro Maia; no Inferno, negreiros, genocidas como Hitler, cowboys assassinos de índios indefesos, e destacados de entre todos, "os senhores economistas", novos cavaleiros de um "apocalipse" sócioeconómico (MELO, 2014, p. 222) em escala global. Todavia, essa relação espaço-personagem não é unívoca ou completamente ortodoxa em Lugar Caído no Crepúsculo, pois a aparente arbitrariedade da misericórdia divina torna incerto o destino da alma no Além. Isso é muito claro no protagonista-narrador do Paraíso, cuja "surpresa total" (MELO, 2014, p. 139) consiste em não ter ido parar ao Inferno devido à sua riqueza e apostasia. Já na morada celestial, a personagem apercebe-se de que Deus perdoará todos os desvios existenciais, incluindo o suicídio de um homem, o que de acordo com a ortodoxia católica, nunca daria a essa alma direito de entrada no Paraíso. Porém, Deus Deu, como se lhe refere o narrador intradiegético, ficara apiedado pela fé da sua mater dolorosa, não havendo tido a mesma sorte outros suicidas, mandados quer para o Limbo quer para o Inferno. Desse modo, tal como na Terra, também no Céu, ou seja, no Além, parece haver arbitrariedade nas decisões, dois pesos e duas medidas, tudo dependendo da vontade do decisor, seja este o Supremo Juiz do mundo, seja um juiz terreno. A mesma arbitrariedade parece estar na facilidade e rapidez com que se decreta o fim de um espaço escatológico com séculos de tradição: o Limbo. O Autor apenas começa por este espaço escatológico, à semelhança de Dante, não para lamentar os que aí ficaram suspensos por estarem "sem baptismo, que é a porta da fé" (DANTE, livro I, canto IV, v. 35-36), mas para satirizar a demora do Vaticano na reparação de uma evidência 
e comprovar a força da vontade humana, neste caso, da alma Erasmo Fernandes, aí caída, ironizando contra essa "antecâmara do Paraíso" à "qual a santíssima Igreja Católica resolveu pôr o nome de Limbo" (MELO, 2014, p. 37), cujas doçuras de existência não dão resposta à "espera sem esperança" (MELO, 2014, p. 55) do Paraíso para milhões de almas, só por não terem sido baptizadas, injustiça divina e teológica sardonicamente questionada diante de montanhas colossais de bebés inocentes e de gerações cujo único azar foi terem nascido antes do "Bom Pastor" (MELO, 2014, p. 52). O pedido de extinção do Limbo levado a cabo por Erasmo (de facto, decretada por Bento XVI em 2007) acaba por desencadear a aparição do Sumo Pontífice, qual deus ex machina, para anunciar a satisfação do pedido: bastara, para tal, um simples "decreto papal [...] lavrado em meia dúzia de linhas" (MELO, 2014, p. 75). O insólito, nesse caso, é que o Limbo é descrito no romance de João de Melo como um espaço escatológico cuja existência e extinção depende de uma instituição humana, o Vaticano, e esse decreto dita o fim do marasmo e a explosão de gáudio de biliões de almas aí amontoadas que transitam directamente para o Paraíso. O insólito está, pois, nesta inversão da lógica: João de Melo sabe bem, e o leitor também, que a existência e as características de um espaço escatológico serão independentes de decretos humanos. Tal inversão deixa de sobreaviso o leitor face a novas surpresas na descrição do restante Além. E aqui desaguamos em dois novos aspectos insólitos: a assertividade com que os espaços da morada dos mortos são descritos; e a sua natureza.

Se o Além é um mistério, um desconhecido, "um lugar caído no crepúsculo", e, ao mesmo tempo, o Autor investe no derrube 
de dogmas católicos e crenças populares (açorianas inclusive), não deixa de ser curiosa, nesse contexto, a descrição assertiva do Limbo, do Purgatório, do Paraíso e do Inferno. Substituemse dogmas por revelações, mas essas revelações desconstroem insolitamente os imagotipos ditados pela dogmática e pela tradição. O discurso contundente é explícito na seguinte frase do cronista do Purgatório: "Com o sentido posto na minha clara certidão da verdade, direi que este purgatório não conta com a presença física de Deus, mas sim com a luz, a palavra e a certeza da sua voz." (MELO, 2014, p. 86). E descrevendo "esta estação existencial" (MELO, 2014, p. 113), diz o cronista, usando de um tom assertivo e piedoso que termina em clave humorística:

A ignorância dos homens acerca do Purgatório faz parte dos muitos dogmas que nos foram impostos a propósito do Além. [...] § Considerome devidamente autorizado a fazer-vos uma única e necessária revelação: tirai das vossas mentes a ideia espúria de que o Purgatório seja um sítio de brasas acesas e línguas de fogo em crepitação, onde ardam almas em manifesto suplício [...]. Essa é tãosó uma imagem, ainda que gravemente lesiva dos bons propósitos da caridade e da intenção do bem que define o Pai. Recomenda-me Ele, meu Senhor, deixar aqui escrito que já por essa perversão, inventada por uns falsos teólogos na chamada Idade Média do mundo, pagaram justamente os seus malévolos autores. Já alguém viu um Pai de verdade a mandar para dentro do forno, como se fora lenha para avivar o lume, ou pão de milho para cozer, ou sardinha para assar sobre as brasas, um dos seus amados filhos na hora de o punir e de o emendar, por mais torto e arredio que tenha nascido? (MELO, 2014, p. 80-83) 
Já o acto de morrer é desmistificado pelo protagonista do Céu, que nega ter visto túneis "de luz" ou ouvido "acordes de harpa", tudo imagens que fazem parte, afirma, "da mitologia da morte, não propriamente da sua verdade" (MELO, 2014, p. 128). Mas o Paraíso reserva-Ihe um grande desgosto: a ausência da visão de Deus, cujo rosto, afinal, ninguém vislumbrara, nem mesmo os Anjos, o que contraria a definição católica de Paraíso, como não pode deixar de reparar quem lê a epígrafe introdutória desse espaço escatológico que o Autor tem o cuidado de colocar no texto.

A natureza do Além é outra das questões insólitas desse romance, e que só pode ser entendida em termos narrativos graças à noção deleuziana de rizoma. A doutrina contemporânea da Igreja Católica despe o Além da materialidade que outrora o caracterizava para significar agora um estado de espírito mais ou menos próximo de Deus e de onde estão excluídos, por exemplo, os microespaços físicos dos caldeirões a ferver do Inferno ou do Purgatório medievais. Assim, na epígrafe do "Sexto Caderno" de Lugar caído no crepúsculo, retirada, conforme avisa o Autor em Nota inicial, do Catecismo da Igreja Católica, datado de 1993, surge esta definição: "E é este estado de auto-exclusão definitiva de comunhão com Deus e com os bem-aventurados que se designa pela palavra Inferno." (MELO, 2014, p. 181). Trata-se, pois, de um espaço psicológico. Definições que excluem um espaço físico concreto para o Purgatório, por exemplo, são igualmente inscritas na qualidade de epígrafe no início do "Quarto Caderno", com base no mesmo Catecismo: "A Igreja chama Purgatório a essa purificação final dos eleitos, que é absolutamente distinta do 
castigo dos condenados." (MELO, 2014, p. 77). Ou seja, o Purgatório não é um espaço físico propriamente dito, mas um processo, um espaço psicológico que implica tempo. Algumas palavras iniciais do cronista do Purgatório vincam a espiritualidade desse espaço:

Trata-se de mais um desses não-lugares que existem só por si, no mistério ignorado do grande Além. Com um nome, uma história, uma maldição. De novo na condição existencial da alma. Onde tempo e espaço não passam de pura ilusão espiritual. Tomai vós, por mero ponto de partida, a ideia de infinito ou de eternidade. Que é isso de não existir um princípio nem um fim para o tudo e para o nada no Além? Entendo que não vos seja possivel compreendê-lo. Pior ainda, para mim, ter de vo-lo explicar. (MELO, 2014, p. 79)

Desse modo, o cronista parece ser o alter ego do Autor que, por infracção metaléptica, se dirige ao leitor, mostrando-Ihe o quanto é difícil este compreender o infinito e a não materialidade do Além, sendo ainda mais difícil, por conseguinte, a tarefa de descrevê-lo. Não é por acaso que o relator do Purgatório prefere a expressão "estação existencial" (MELO, 2014, p. 113) a espaço, tal como sucede com o narrador-protagonista do Paraíso. Como descrever, de facto, um espaço escatológico despido de materialidade, ou seja, sem coordenadas físicas? O Além de João de Melo é, neste sentido, muito mais desafiante do que o outro mundo descrito n'A divina comédia, de Dante - perdoem-nos se alguém considerar abuso tal cotejo -, pois o Além do poeta florentino assenta na materialidade física dos espaços visitados. Cícero, guiando o poeta nos seus primeiros passos nesse mundo temível, instiga-o a ter coragem: "Ora desçamos, pois, ao cego 
mundo" (DANTE, livro I, canto IV, v. 13), o que não deixa margem para dúvida do uso do topos da catábase ao Hades. Nesse Inferno cristão não faltam rochedos duros, estradas por onde caminham dolentes condenados, esterco onde outros chafurdam, desertos de areia, pontes, labaredas de fogo que torturam almas condenadas, lagos de gelo e a gruta onde mora Belzebu. Como indica o tradutor português d'A divina comédia:

[...] as regiões das almas dos mortos que percorre são figuradas geometricamente com um rigor sem concessões, aliás presente de muitos modos na própria estrutura da obra. O Inferno é um imenso oco em forma de cone vazio invertido ou funil aberto na rocha, em cujo interior os percursos descendentes participam da obsessão arquetípica do labirinto, em círculos sucessivos, até ao vértice, no exacto centro da Terra, onde se encontra enfiado Lúcifer desde a queda inicial. O Purgatório é um outro cone, desta vez elevado acima das águas, no hemisfério austral. (...) A subida do monte do Purgatório processa-se em espiral, pelo exterior, e também em círculos sucessivos. No cume, encontra-se o Éden ou Paraíso Terrestre. (...) O Paraíso Celeste, por sua vez, é uma sucessão de círculos concêntricos, feitos de luz, figurações, simetrias e rotações de fogo gerando uma irreproduzível harmonia das esferas. (DANTE, 2000, p. 18-19)

Mas, como descrever um espaço imaterial sem recorrer à terminologia do espaço físico, dadas as nossas limitações de entendimento do Ser fora de um tempo e fora de um espaço, como indica Gama-Khalil, referindo Foucault? (cf. GAMA-KHALIL 2012, p. 30). Assim, 
via da regra, algumas noções da teoria literária tradicional (como espaço físico, espaço social, por exemplo) são insuficientes para uma análise que dê conta da hibridez, dispersão e pluralidade do espaço insólito. (GAMA-KHALIL, 2012, p. 35)

João de Melo parece obedecer ao preceito da não materialidade dos espaços escatológicos e daí que o narrador do Purgatório insista em definir o Além como um "não-lugar" (MELO, 2014 , p. 119), porque fora do tempo e do espaço, algo em que insistem quer o narrador-protagonista do Purgatório, como já foi visto, quer o narrador do Paraíso:

Porque o Além não é uma distância, nem um lugar que possa ser contido entre o início e o fim de uma dimensão espacial - mas antes um desejo, quem sabe se uma ideia para a continuidade da vida, que em cada um de nós se volta para o alto e para o infinito. Dele, melhor se diria ser como uma estação a que nunca se chega; de onde também não se pode nunca voltar a partir: tudo, nessa estação, pertence ao fulgor da mais pura inexistência material. É o que sei e posso revelar-vos. (MELO, 2014, p. 140)

Uma vez que a opção insólita de João de Melo é afirmar categoricamente a imaterialidade dos espaços escatológicos que cada narrador-protagonista aí residente vai marcar, com maior ou menor explicitude, o que se coaduna com a espiritualização desses espaços no catecismo católico contemporâneo, é devolver em simultânea materialidade a esses espaços, pois a descrição de nenhum deles prescinde de terminologia geográfica, ou seja, de vocabulário do espaço físico, o que implica um regresso parcial ao paradigma d'A 
divina comédia, de Dante. Há uma associação paradoxal do imaterial afirmado com o sensível descrito, constituindo, desse modo, o Além, um insólito espaço rizomático.

Assim, nesta nova "teoria do homem", como define Miguel Real (2015, p. 15) neste romance de João de Melo, o Limbo surpreende o seu mais recente habitante, a personagem Erasmo Fernandes, pela "espécie de nuvens esparsas que se sobrepõem umas às outras, por ali acima, como se mais não fossem do que castelos aéreos, navios voadores, montanhas suspensas do $\operatorname{ar}^{\prime \prime}$ (MELO, 2014, p. 35). Contudo, o que mais surpreende este narrador-protagonista do Limbo são as "montanhas", as "Montanhas Verdadeiras" formadas por bebés não batizados, "altíssimas serranias de seres a perder de vista no nimbo azulado e violeta das suas silhuetas" (MELO, 2014, p. 44-45). O relevo escolhido e a forma superlativa do adjectivo pretendem enfatizar a injustiça da concepção teológica do Limbo. Todavia o narrador é ainda peremptório na sua descrição, recorrendo a expressões do espaço físico para dar conta do aspecto do Limbo, que, variado orograficamente, também abrange "Vales Frondosos", "Frescos Desfiladeiros", "Colinas Verídicas", "Planícies Aéreas" "e outras tantas paisagens exclusivas do nosso Limbo" (MELO, 2014 , p. 45). Os espaços físicos simplesmente aparecem como que refinados ou etéreos, dado o facto de o Limbo ser aqui a antecâmara do Paraíso.

Quanto ao Purgatório, se bem que o seu narrador finque a natureza de "não-lugar" daquela "estação existencial", como já referido, não deixa de ser paradoxal o mesmo narrador começar assim o seu relato do Purgatório por esta descrição: 
Bem ou mal comparado aos olhos de quem chega, o que acerca deste purgatório posso eu dizer-vos é ser ele em tudo semelhante a um vale muito cavado, extenso e árido entre montanhas igualmente nuas. Cálido, agreste, poeirento, mais inóspito e mais cruel do que um deserto batido pelos ventos ardidos e inclementes da morte. Grande e fundo como o mar. Estamos no mais alto do Céu ou no centro oculto do planeta Terra? Pois nem uma coisa nem outra. Trata-se de mais um desses não-lugares que existem por si, no mistério ignorado do grande Além. (MELO, 2014, p. 79)

O narrador começa, pois, por utilizar uma linguagem própria da descrição de um espaço físico mimético, entrando em detalhes que traduzem o carácter inóspito do lugar, mas pouco depois passa a negar a localização espacial do mesmo (nem em baixo nem no alto) e até a sua materialidade, mais adiante. O uso deste vocabulário serviria, pois, apenas de muleta metafórica para descrever aquilo que a mente humana não consegue abarcar. A linguagem assume-se como preterição: está aquém da possibilidade descritiva desse Além.

O narrador que nega a materialidade do Paraíso - "Somos, simultaneamente, forma e não-espaço" (MELO, 2014, p. 147) descreve a magnífica paisagem dessa estação existencial utilizando terminologia característica do espaço físico:

Conheci muitas das solenes maravilhas do planeta (...). Mas nunca em nenhuma parte eu vi um sítio tão belo nem tão perfeito como este. O Paraíso? Tinham razão os gregos em crerem na montanha do Olimpo como morada perfeita dos seus deuses. Só que o Deus meu criador não se ficou por uma, mas por uma sucessão de montanhas perfiladas 
no horizonte, qual cordilheira a perder de vista. Nenhuma dessas montanhas é mais extraordinária na sua beleza do que a montanha seguinte. § Havia o claro predomínio de uma cor sobre as demais, em cada uma delas e por isso tomavam o nome da sua cor mais característica. Diferenciavamse entre si também pela altura, pelas formas bojudas ou atarracadas, pelo número sempre extraordinário dos seus lagos, jardins e pomares; sobretudo pelas miraculosas obras de criação em que se constituíam as suas paisagens aéreas, assentes sobre um mar de nuvens suspensas no espaço infinito do Além. (MELO, 2014, p. 143)

A mimese física destas montanhas paradisíacas só é desconstruída pela excelsa maravilha das mesmas e pelo facto de, no final da sua descrição, se indicar que o conjunto infindável desse relevo assenta em nuvens. Aí reside o insólito: essa mistura de verosímil e inverosímil para traduzir aquilo que o narrador conclui como sendo a possível natureza rizomática daquele espaço: "A beleza da paisagem era a nossa felicidade" (MELO, 2014, p. 144).

Por fim, um desumanizado ex-corretor da Bolsa de Lisboa fica surpreso com o Inferno, uma superfície desolada toda coberta de neve. A descrição paródica da primeira impressão causada por este Inferno alternativo, que se vai tornando cada vez mais terrível, todavia, está patente no seguinte trecho:

Não havia fogo nem fumo, nada ardia nem estrelejava no ar. E por isso não era possível escutar a crepitação das labaredas, nem sentir o tal cheirinho imaginário a refogado, o que bem poderia ter alegrado um pouco mais o que ainda lhe restava dos cinco sentidos. (MELO, 2014, p. 203) 
O Inferno reservará, todavia, surpresas ainda mais desagradáveis, que culminam no abocanhar físico da carne dos condenados pelos lobos dos demónios - uma alusão rizomática aos cães dos campos de concentração - e no congelamento individual de cada condenado num bloco de gelo, cela isolante de todo o contacto físico ou emocional com outro ser, até à alienação total.

\section{CONCLUSÃO}

Como indicamos em recensão crítica feita a este romance, a

redefinição paródica do Além daqui resultante não significa, pois, uma zombaria à fé, que o Autor até desejaria ter, mas uma outra visão possível do lado de lá, que a literatura lhe dá a liberdade de imaginar. E o Paraíso é elogiado neste romance como o espaço por excelência da liberdade. (VIEIRA, 2015, p. 214).

A descrição de um Além que é afirmado ser infinito e imaterial esbarra com os limites da linguagem e do entendimento humano, coibindo João de Melo de utilizar termos ou expressões próprios do espaço físico, construindo um espaço escatológico rizomaticamente paradoxal, porque material e imaterial em simultâneo. Ao mesmo tempo, a via de acesso ao Além, o Tejo, é um espaço rizomático, porque insolitamente também é via de passagem obrigatória para o Inferno. E esse outro lado da vida permanece um mistério, mesmo depois de descrito como uma revelação pautada por surpresas. 


\section{REFERÊNCIAS}

Dante, A. (2000). A divina comédia (5ed.). (V. G. Moura, Trad.). Lisboa: Bertrand. Duarte, L. R. (2014). João de Melo: Viagem ao fim do Além (1150, p. 14-15) [entrevista]. Jornal de Letras, Artes e Ideias.

Fernandes, R. M. R. (1993). Catábase ou Descida aos Infernos (XLV, p. 347-359). Alguns exemplos literários. Hvmanitas. In http://www.uc.pt/fluc/eclassicos/ publicacoes/ficheiros/humanitas45/19 Rosado Fernandes.pdf Acesso em outubro/2015.

Gama-Khalil, M. M. (2012). As teorias do fantástico e a sua relação com a construção do espaço ficcional. In F. García \& M. C. Batalha (Ed.). Vertentes Teóricas e Ficcionais do Insólito (p. 30-38). Rio de Janeiro: Editora Caetés.

García, F. (2012). Quando a manifestação do insólito importa para a crítica literária. In F. García \& M. C. Batalha (Ed.). Vertentes Teóricas e Ficcionais do Insólito (p. 13-29). Rio de Janeiro: Editora Caetés.

Homero. (2003). Odisseia (F. Lourenço, Trad.). Lisboa: Cotovia.

Horácio. (2008). Odes (P. B. Falcão, Trad.). Lisboa: Cotovia.

Marinho, M. de F. (1999). O romance histórico em Portugal. Porto: Campo das Letras.

Melo, J. (1990). Entre Pássaro e Anjo (2ed.). Lisboa: Dom Quixote.

. (2009). A Divina Miséria. Lisboa: Dom Quixote.

- (2014). Lugar Caído no Crepúsculo. Lisboa: Dom Quixote.

. (2015). Memória(s): A minha história com Ferreira de Castro (1155, p. 32).

Jornal de Letras, Artes e Ideias.

Paganini, D. A. (2014). Hoje católico. Defesa e apologia da fé católica. Dogmas sobre a morte e o Além. In http://frontcatolico.blogspot.pt/2014/05/dogmassobre-morte-e-o-alem.html Acesso em outubro/2015.

Real, M. (2014). Teoria do Homem (1150, p. 15). Jornal de Letras, Artes e Ideias. Reis, C. (2012). Figurações do insólito em contexto ficcional. In F. García \& M. C. Batalha (Ed.). Vertentes Teóricas e Ficcionais do Insólito (p. 54-69). Rio de Janeiro: Editora Caetés.

Vieira, C. C. (2008). A construção da personagem romanesca. Processos definidores. Lisboa: Colibri. 
- Vieira, C. C. (2012). Heterodoxias ficcionais e historiográficas no romance saramaguiano: o desejo e a morte em História do cerco de Lisboa e As intermitências da morte. Convergência Lusíada (p. 65-93). In http://www. realgabinete.com.br/revistaconvergencia/?p=1955 Acesso em outubro /2015. _. Vieira, C.C. (2015). João de Melo. Lugar Caído no Crepúsculo (190, p. 211214) Colóquio/Letras. 